Dampak Sosio-Ekonomi Piala Dunia terhadap lingkungan domestik Brasil

\author{
Wahid Noor Jayn
}

\begin{abstract}
Abstrak
Sepakbola dan politik memang tidak berkaitan langsung. Namun, sepakbola bisa memberikan dampak politik berskala nasional bahkan internasional. Politisasi olahraga adalah upaya yang 'lazim' digunakan oleh para pemangku kepentingan. Dalam kasus tertentu, upaya politisasi olahraga khususnya sepakbola bisa dilakukan secara sistemik.

Fenomena Dilma Rousseff di Brazil yang, selama tidak kurang dari 3 tahun terakhir sejak 2013, didesak mundur karena 'kecerobohan' dalam perumusan arah kebijakan nasional terakumulasi pada periode April - Mei yang lalu. Kekecewaan masyarakat terhadap Dilma disebabkan oleh lambannya perekonomian dalam negeri. Disamping itu, masalah sosial dan kesehatan seperti pengangguran, kriminalitas, kemiskinan, dan munculnya wabah penyakit serta kasus korupsi masif yang melibatkan para pejabat bahkan mantan Presiden Lula da Silva turut memperparah kondisi domestik. Ironisnya, janji-janji pembukaan lapangan kerja dan kesejahteraan masyarakat yang akan meningkat seiring dengan akan digelarnya Piala Dunia 2014 tidak lebih dari sekedar harapan palsu. Penulis berpendapat bahwa demonstrasi dan tuntutan terhadap pemerintah memiliki kaitan baik langsung maupun tidak langsung dengan penyelenggaraan Piala Dunia

Analisa pada tulisan ini didasarkan pada fenomena yang sedang terjadi untuk kemudian diperbandingkan dengan apa yang seharusnya dilakukan.

Kata kunci: FIFA, Brasil, Dilma Rousseff, Pembangunan, Piala Dunia
\end{abstract}


Pendahuluan

Sepakbola mengatasnamakan apa saja bisa tampak di bidang politik. Dalam beberapa kasus, sepakbola menjadi barometer ideal dalam hubungan internasional, ketegangan antar bangsa, serta ambisi nasional. Sebagai contoh negara-negara yang baru merdeka langsung mencari legitimasinya dengan mengajukan syarat menjadi anggota FIFA yang jumlahnya lebih banyak daripada anggota PBB (Perserikatan BangsaBangsa). Menurut laporan terbaru dari Kongres FIFA pada 25 Mei 2012, Sudan Selatan menjadi anggota ke-209 (FIFA.com). Hal ini menunjukkan bahwa sepakbola telah merangkul semua bangsa dan negara di dunia tanpa memandang kekuatan negara, baik dari segi kekuatan ekonomi, politik, sosial, dan budaya, serta setiap negara ingin memperoleh pengakuan dunia internasional dalam konteks persaingan sepakbola internasional.

Sepakbola terkadang dijadikan sebagai alat kampanye politik, mobilisasi massa hingga propaganda. Melihat sejarah penyelenggaraan Piala Dunia dari pertama kali digelar pada 1930 di Uruguay, Brasil merupakan tim yang paling banyak memenangkan turnamen ini dengan koleksi 5 gelar. Selain itu, Brasil adalah negara yang selalu tampil di setiap turnamen Piala Dunia.

Pada 2014, sebagai tuan rumah mereka berambisi dan berupaya mengangkat trofi keenamnya, yang dahulu bernama Trofi Jules Rimet. Sayangnya perjuangan Brasil harus terhenti di babak semifinal setelah dihancurkan oleh Jerman 7-0, dan Jerman pula lah yang akhirnya keluar menjadi juara dunia. Pada 1950, Brasil juga pernah menjadi tuan rumah dan hampir saja memenangi kejuaraan sebelum akhirnya kalah dari Uruguay di partai puncak yang digelar di stadion legendaris, Estadio do Maracanã dengan skor 2-1 yang kemudian dikenal dengan istilah Maracanazo, mengacu pada kegagalan tim Samba tersebut.

Menjadi penyelenggara event sekelas Piala Dunia adalah impian hampir setiap negara di dunia. Sekurang-kurangnya, turut berpartisipasi sebagai peserta pun sudah cukup membangkitkan euforia tersendiri bagi 
masyarakat negara yang bersangkutan. Hal ini pula yang dialami oleh Tahiti (FIFA.com). Sebagai negara perwakilan dari zona Oseania karena menjuarai Piala Oseania (OCF Zone), Tahiti berhak tampil di ajang Piala Konfederasi 2013, yaitu pagelaran 'pembuka' setahun sebelum penyelenggaraan Piala Dunia di mana para pesertanya merupakan para juara di tiap kontinen atau benua yang berada di bawah naungan FIFA.

Mendapatkan kehormatan sebagai salah satu peserta, Tahiti berkesempatan unjuk gigi kepada dunia akan eksistensi sebuah negara kecil yang terletak di Pasifik. Eksposur media internasional kiranya sudah cukup bagi Tahiti untuk dikenal dunia--setidaknya bukan hanya karena prestasi mereka menjuarai Piala Oseania--alih-alih 'prestasi' mereka yang sukses menjebol 1 kali jala lawan dan kebobolan 24 gol! Kendati demikian skuat Tahiti cukup bangga bisa mendapatkan pelajaran berharga dari timtim kelas dunia di turnamen ini- mereka berada satu grup dengan Spanyol (Juara Dunia 2010), Uruguay (Juara Copa America 2011), dan Nigeria (Juara Piala Afrika 2013).

Pembahasan

Sedikitnya terdapat tiga poin utama yang akan menguntungkan negara penyelenggara Piala Dunia. Pertama, dilihat dari kepentingan negara, Piala Dunia merupakan ajang prestisius yang akan mampu menaikkan status dan citra di dunia internasional. Prestige, status, dan citra memang bukan satu-satunya indikator yang menjadikan sebuah negara dihormati dan disegani. Namun perlu diingat pula bahwa pengakuan (recognition) adalah salah satu sifat alamiah makhluk hidup, dan negara merupakan kumpulan makhluk-makhluk hidup (zoon politicon)-dalam hal ini kita dapat mengacu pada hirarkhi kebutuhan Abraham Maslow.

Citra positif sebuah negara akan berdampak positif pada sektorsektor penopang pembangunan, seperti industri, dampak sosial, serta pariwisata. Misalnya minat investor untuk berinvestasi di negara yang aman, baik itu aman secara psikologis maupun politik akan meningkat. Belum lagi jumlah turis baik lokal dan mancanegara yang akan meningkat 
selama pagelaran ini dihelat dan juga pada tahun-tahun berikutnya mengingat pada 2016 Brasil juga akan menjadi tuan rumah Olimpiade. Pada praktiknya, negara manapun di dunia tidak mau disebut dengan sebutan negara miskin atau terbelakang. Ini yang kemudian penulis sebut dengan citra karena berkaitan pula dengan harga diri bangsa (national dignity). Keberhasilan atau kegagalan dalam penyelenggaraan sebuah turnamen besar akan berdampak pada eksistensi negara tersebut dalam pergaulan internasional. Posisi tawar sebuah negara bisa naik dan tidak jarang pula turun hanya karena sebuah penyelenggaraan turnamen sepakbola atau bahkan hanya dalam sebuah pertandingan.

Kedua, keuntungan dari segi ekonomi tidak bisa tidak adalah hal mutlak yang akan diterima oleh negara penyelenggara. Menurut studi dan laporan (Ernst \& Young Terco, 2011), dampak dari pelaksanaan Piala Dunia di Brasil dalam periode 2010-2014 diproyeksikan mencapai $\mathrm{R} \$ 142$ Miliar atau setara dengan Rp 763 Triliun! (kurs 1 BRL $=$ Rp 5371). Pada Piala Dunia 2010 lalu, Menteri Keuangan Afrika Selatan berbicara pada Business Times, dihimpun dari kompas, menyatakan bahwa GDP Afsel naik 0,4 poin dan negara meraup keuntungan Rp. 49,4 Triliun.Masuk akal kiranya apabila banyak negara berlomba ingin menjadi tuan rumah Piala Dunia jika melihat angka-angka diatas dan tentu saja hal itu akan bagus bagi pembangunan dan pertumbuhan ekonomi makro -maupun mikro- negara yang bersangkutan.

Ketiga, tersedianya lapangan pekerjaan baru. Pelaksanaan Piala Dunia sedikit banyak membantu pemerintah dalam menanggulangi pengangguran terlebih bagi negara penyelenggara yang memilki jumlah penggangguran yang tinggi, seperti di Brasil. Pada 2009, jumlah pengangguran di Brasil mencapai 8,1 \%. (The Wall Street Journal, 2009). Setidaknya, Piala Dunia kali ini telah membuka satu juta lapangan pekerjaan baru yang bisa membantu kehidupan ekonomi masyarakat setempat (Ernst \& Young Terco, 2011). 
Selain itu, konsep menarik yang dibuat oleh panitia pada penyelenggaraan Piala Dunia di Brasil adalah dengan mengambil tema Green World Cup dengan mengangkat isu Global Warming. Brazil sebagai paru-paru dunia dengan keanekaragaman makhluk hidup dan hutan Amazon yang lebat, mengajak kepada dunia untuk lebih menghargai lingkungan dan alam sekitar. Hal ini tertuang dalam kebijakan lokal pemerintah yang sejalan dengan tema penyelenggaraan Piala Dunia 2014 (2014 FIFA World Cup ${ }^{T M}$ Sustainability Strategy - Concept, 2012).

Lalu, mengapa hingga beberapa jam sebelum pembukaan Piala Dunia masih terjadi demonstrasi penolakan dan protes Piala Dunia di kota-kota di Brasil? Bukankah masyarakat akan banyak diuntungkan dengan penyelenggaraan ini?

\section{FIFA dan...uang?}

Tidak sedikit yang mengira bahwa yang akan banyak diuntungkan dengan penyelenggaraan Piala Dunia adalah FIFA, induk organisasi sepakbola dunia, alih-alih tuan rumah. Pemasukan dari sponsor dan mitra kerjasama FIFA mencapai US\$3,655 juta! (FIFA Financial Report, 2010) mungkin bisa juga disebut sebagai Federation of International Fund Assosiation. Penulis berpandangan bahwa spanduk protes bertuliskan "FIFA Go Home" mengindikasikan dan menguatkan opini bahwa 'ada sesuatu yang tidak beres' dalam diri FIFA, juga termasuk dalam penyelenggaraan Piala Dunia.

Hal ini mengingatkan pada kasus suap dan dugaan jual beli suara dalam pemenangan tuan rumah Piala Dunia 2018 Rusia dan Piala Dunia 2022 Qatar. Ketika itu, Inggris--yang juga menjadi calon tuan rumah dan mengikuti proses biding untuk 2018--bahkan menjanjikan keuntungan besar bagi FIFA jika mereka terpilih. Nyatanya mereka tersisih dan mereka menuding--sebagaimana dilansir dari media Inggris--ada konspirasi di dalam tubuh FIFA (news.sky.com, 2011). Kendati demikian, justru hal ini patut mendapat perhatian serius. Bahkan beberapa anggota eksekutif FIFA terbukti menerima suap dan mereka menjadi pesakitan meskipun tidak 
menggugurkan Rusia dalam pelaksaan Piala Dunia 2018 yang akan datang. Isu ini kemudian disusul dalam beberapa pekan berikutnya bahwa ada juga dugaaa pemenangan Qatar 2022 kentara dengan 'aksi tipu-tipu'. Parahnya, mitra setia FIFA seperti Adidas, Sony, Visa, Hyundai dan sponsor lainnya mengancam akan menarik diri jika dugaan ini benar (Rustam Agus, 2014)

Belum habis sampai di sini, FIFA kembali membuat kebijakan yang dianggap kontroversial. Tersingkirnya beberapa negara unggulan dalam Piala Dunia kali ini seperti juara bertahan Spanyol, Italia dan Inggris membuat FIFA secara sepihak 'merasa curiga' terhadap negara-negara semenjana seperti Kosta Rika yang secara fenomenal menjuarai Grup D bersama dengan Uruguay serta dua negara yang terakhir disebut. 'Konsekuensinya' FIFA melakukan tes doping pada 7 pemain Kosta Rika. FIFA berdalih itu adalah tes normal yang harus dilakukan pemain sesuai prosedur yang berlaku. Namun, keputusan ini terlanjur menjadi preseden buruk terhadap organisasi yang dipimpin Sepp Baltter kala itu

Di tengah sorotan media dan banyaknya protes, ketegasan dan sikap FIFA diuji ketika pada pertandingan terkahir babak penyisihan grup antara Uruguay dan Italia (24/06/2014), Luis Suárez kembali 'memangsa'. Kali ini yang menjadi korban adalah Giorgio Chiellini. Sang pemain belakang terkapar akibat gigitan Suarez di bahu kirinya. FIFA yang segera melakukan investigasi akhirnya memutuskan bahwa Suarez bersalah dan dijatuhi hukuman 4 bulan tidak boleh aktif dalam sepakbola dan suspended 9 pertandingan internasional bersama Uruguay. Kali ini keputusan FIFA dianggap tepat dan mendapat banyak pujian dan kritikan, khususnya dari pihak Uruguay. Namun belakangan FIFPRo, sebagai organisasi pemain sepakbola profesional, juga melayangkan kritikan kepada FIFA terkait hukuman yang dijatuhkan pada el pistolero, julukan Suarez. 


\section{Kebutuhan dasar belum terpenuhi}

Dilma Rousseff, Presiden Brasil kiranya berpandangan bahwa Piala Dunia kali ini juga merupakan bagian dari strategi pembangunan nasional yang akan berdampak baik bagi masyarakat dan negara. Bahkan Luiz Inácio Lula da Silva--presiden sebelumnya--menjulukinya sebagai "ibu pembangunan" (akronim portugis: PAC, Programa de Aceleração do Crescimento).

Beliau menggagas percepatan pembangunan infrastruktur guna menopang dan juga demi kepentingan masyarakat luas. Namun, perlu kita cermati bahwa Sinhora Presidente berpendirian ganda dalam hal ini. Dilma Rousseff yang notabene 'beraliran kiri' justru dihadapkan pada masalah pembangunan yang membutuhkan miliaran dolar alih-laih kesejahteraan masyarakat yang lebih konkrit, seperti investasi di bidang pendidikan dan kesehatan. Konsekuensinya adalah ketidakpopuleran kebijakan ini di mata masyarakat.

Masalah yang dihadapi masyarakat Brasil dikarenakan belum meratanya pembangunan di negara ini. Pembangunan yang dimaksud tidak melulu berhubungan, meskipun kadang berkaitan-dengan pembangunan fisik berupa gedung bertingkat, pusat perbelanjaan, perkantoran dan sebagainya, melainkan pembangunan manusianya itu sendiri. Maksudnya, kebutuhan masyarakat seperti pendidikan, kesehatan, pelayanan publik serta perumahan belum mereka dapatkan dengan layak. Inilah hal yang mendasari masyarakat melakukan protes penyelenggaraan Piala Dunia yang mana pemerintah mengeluarkan biaya yang ditaksir mencapai US\$14 Milyar (ESPNFC.COM). Terlebih kiranya kita bisa memahami jika mengacu pada Konstitusi Brasil, Bab 1 Article 3 yang menyuratkan bahwa "kesejahteraan masyarakat menjadi tujuan utama pemerintah Brasil dalam menjalankan fungsi negara”.

Dengan biaya sebesar itu, alangkah bijaksananya jika diperuntukkan bagi kebutuhan masyarakat mendesak rakyat seperti yang telah disebutkan di atas. Bahkan, seperti diberitakan media massa, transportasi publik 
menjelang pelaksanaan event tidak beroperasi dikarenakan para pekerja melakukan aksi mogok. Mereka menuntut perhatian dan peningkatan kesejahteraan, apalagi menghadapi event sebesar Piala Dunia--yang katanya--banyak menguntungkan masyarakat. Namun, pemerintah Brasil sepertinya sudah menyadari dan mengantisipasi jauh-jauh hari mengenai akan banyaknya aksi protes Piala Dunia. Seperti dikutip dari situs goal.com sejak Mei 2012 lalu, para petugas keamanan diberi pelatihan khusus oleh agen FBI. Hal ini dimaksudkan untuk mencegah tindak kekerasan dan terorisme selama menghadapi event internasional seperti Piala Dunia dan Olimpiade Rio. 
Penutup

Sepakbola sejatinya tidak boleh dipolitisasi seperti halnya olahraga lain karena tentu saja menyalahi kode etik olahraga yang menjunjung tinggi sportifitas. Namun, dalam banyak kasus sepakbola merupakan alat kampanye politik baik oleh individu, kelompok, dan bahkan tingkat negara sekalipun. Kasus dualisme federasi di Indonesia merupakan contoh nyata dari politisasi sepakbola. Kalaupun akan mempolitisasi olahraga, lakukanlah secara profesional. Maksudnya, kesolidan di dalam organisasi merupakan hal mutlak yang mesti dipenuhi.

Proses legalisasi dalam sebuah pelaksanaan event besar sekelas Piala Dunia membutuhkan pemahaman sejalan akan tujuan nasional dari pemerintah dan federasi karena sesungguhnya federasi merupakan kepanjangan tangan dari pemerintah dalam mewujudkan cita-cita nasional.

Sejatinya Piala Dunia bisa dijadikan akomodasi kepentingan negara dalam hubungan internasional dan juga alat yang kepentingan masyarakat dalam memenuhi kebutuhannya. Menjadi anomali jika ada pihak yang merasa dirugikan dengan mega-event sekelas Piala Dunia. Sebaliknya, para pemangku kepentingan mengharapkan dampak positif, merasa bahagia, bangga, sekaligus diuntungkan sesuai dengan slogan FIFA, For The Game For The World. 
Daftar Pustaka

Buku :

Agus Salim,2007, Buku Pintar Sepakbola, Penerbit Jembar, Bandung

Davidoff, Linda L.,1981, Introduction to Psychology, McGraw Hill International, Auckland

Dede Isharuddin, 2008,Drama Itu Bernama Sepakbola: Gambaran Silang Olahraga, Politik, dan Budaya, PT Elex Media Komputindo, Jakarta

Foer, Franklin., 2004,How Soccer Explains the World : The Unlikely Theory of Globalization, HarperCollins Publisher, New York

Steans, Jill dan Lloyd Pettiford, 2009,Hubungan Internasional : Persprektif dan Tema, Pustaka Pelajar, Yogyakarta

The New Encyclopaedia Britannica $15^{\text {th }}$ edition, 2005, Macropaedia, Knowledge in Depth. V 26, USA

\section{KARYA ILMIAH / JURNAL / LAPORAN}

Arafat, 2011, "Peran Diplomasi Sepakbola dalam Peningkatan Hubungan Bilateral Spanyol -Portugal", skripsi, Universitas Hasanudin Makassar

City of Johannesburg Central Startegy Unit. Chapter 10 FIFA World Cup 2010

Doyle, Michael, 1983, "Kant, Liberal Legacies and Foreign Affair" Philosophy and Public Affairs. Vol 12. No 3

Ernst \& Young Terco, 2011, "Sustainable Brazil : Social and Economic Impacts of the 2014 World Cup", Rio de Jeneiro - Ernst \& Young Brazil

FIFA, 2012, '2014 FIFA World Cup ${ }^{\mathrm{TM}}$ Sustainability Strategy - Concept', Version 2- May

FIFA Financial Report 2010

Joshi, Shashank, 2008, "Honor in International Relations". Working Paper Series No 08-0146. Weatherhead Center for International Affairs, Harvard University. 
Merkey, Daniel. "The Prestige Motive in International Relations", Princeton University. 2000

\section{MEDIA MASSA / INTERNET}

— 2012, "Afsel Setelah Piala Dunia", (9 April 2012), bola.kompas.com/read/2010/07/22/1336314/Afsel.Setelah.Piala.Dunia , 2016, 1, (6 Juni 2016) http://online.wsj.com/article/BT-CO20090723-708893.html ,2011, Why Did England Fail With World Cup Bid?, (2 November 2011) http://news.sky.com/home/uk- news/article/15845171

2012, World Cup Set Most Lucrative Ever, (12 April 2012), http://www.espnfc.com/news/story/_/id/1830732/2014- world-cup-setmost-lucrative-ever?cc $=5739$

Rustam Agus, 2014, "Piala Dunia 2022 : Giliran Visa tuntut FIFA tuntaskan isu suap Qatar, (09 Juni http://sport.bisnis.com/read/20140609/58/234266/piala-dunia2022-giliran-visa-tuntut-fifa- tuntaskan-isu-suap-qatar 